Original article

\title{
First-degree family history of cancer can be a potential risk factor among head and neck cancer patients in an isolated Mizo tribal population, northeast India
}

\author{
Lallianmawii Pachuau $^{\mathrm{a}, 1}$, Zothan Zami ${ }^{\mathrm{a}, 1}$, Thanchung Nunga ${ }^{\mathrm{b}}$, R. Zodingliana ${ }^{\mathrm{b}}$, \\ Rita Zoramthari $^{\mathrm{b}}$, R. Lalnuntluanga ${ }^{\mathrm{b}}$, Zonun Sangi ${ }^{\mathrm{b}}$, Lal Rinmawii ${ }^{\mathrm{b}}$, \\ Nachimuthu Senthil Kumar ${ }^{a}$, H. Lalhruaitluanga ${ }^{\text {a," }}$ \\ ${ }^{a}$ Department of Biotechnology, Mizoram University, Aizawl, 796001, Mizoram, India \\ b ENT Department, Civil Hospital Aizawl, Aizawl, 796001, Mizoram, India
}

\section{A R T I C L E I N F O}

\section{Keywords:}

HNSCC

Family history of cancer

Alcohol

Zozial

Mizo

\begin{abstract}
A B S T R A C T
Background: Head and Neck Squamous Cell Carcinoma (HNSCC) is commonly associated with tobacco and alcohol consumption. The aim of this study is to find the association between the risk factors with HNSCC in a small tribal population of Mizoram, North-East India.

Methods: Data were obtained through consented questionnaires and Logistic Regression was used to calculate the Odds Ratio (OR) between the parameters and HNSCC.

Result: Significant association was observed for smoking and alcohol with an OR of 6.703 and 4.527, respectively. The OR was found to increase with increase in smoking and alcohol consumption. Majority of the patients consumed local made alcohol and smoked the local made cigarettes known as Zozial. Moreover, the First-Degree Family History of Cancer showed a significant OR of 1.921 (95\% CI: 1.040-3.547).

Conclusion: Regardless of the duration of smoking or alcohol consumption, Family History of Cancer might influence the risk of HNSCC. Further screening is essential to evaluate the potential role of germline mutational effect on development of HNSCC in the population.
\end{abstract}

\section{Authors' contributions}

TN, RZL, RZT, RL, ZS, LR recruited the patients. LP, ZZ obtained questionnaires and performed the data analysis. LP, ZZ, NSK, HL interpreted the data and wrote the manuscript. All authors have proof read and approved the manuscript.

\section{Introduction}

Squamous Cell Carcinoma arising from the mucosal epithelium of the Oral Cavity, Hypopharynx, Nasopharynx, Larynx, Oropharynx, Paranasal Sinuses and Nasal Cavity are collectively termed as Head and Neck Squamous Cell Carcinoma (HNSCC) (https://www.cancer.gov). According to GLOBOCAN, Head and Neck Cancer is the eighth most common cancer worldwide with 833,519 cases and 467,125 deaths in the year 2020. ${ }^{1}$ In India, Mizoram state ranks sixth among males in Head and Neck Cancer. ${ }^{2}$ In Mizoram, Oral Cavity, Larynx, Nasopharynx and Hypopharynx are among the top ten cancer cases between the year 2014-2016. ${ }^{3}$

Mizoram is a small indigenous state located in the North Eastern Region of India, where the population has practiced endogamy over centuries. The people of Mizoram are ethnically Mongoloids with distinct culture and lifestyle habits from that of mainland India. Majority of HNSCC appears to be sporadic as long-term exposure to carcinogens can result in accumulation of somatic mutations which increases the chance of developing cancer. However, with the rising cases of young patients $(<45$ years of age) with HNSCC, studies have also shown the potential role of germline effect in HNSCC. ${ }^{4,5}$ Several authors have reported an increased susceptibility of HNSCC among patients with family history of cancer, ${ }^{6,7}$ but has not been explored in a cancer prone small

\footnotetext{
* Corresponding author. Department of Biotechnology, Mizoram University, Aizawl, 796001, Mizoram, India.

E-mail address: mahruaia123@gmail.com (H. Lalhruaitluanga).

1 Both the authors contributed equally.
} 
tribal population practicing endogamy.

Consumption of tobacco, smoked food, alcohol and areca nut chewing has been a practice for many generations among the Mizo population. Tobacco is consumed in the form of smoking (cigarette), dipping (sahdah), chewing/ingested (gutkha products) and smokelessinfused water called as 'tuibur'. Tuibur is either smoked with a pipe or placed in the mouth as long as the consumer desires and then spit out. Branded cigarettes and locally hand-rolled unfiltered cigarettes called as 'Zozial' are available in the state. Tobacco Specific Nitrosamines (TSNAs) and Polycyclic Aromatic Hydrocarbons (PAHs) are well studied carcinogens found in cigarettes as well as smokeless tobacco products. ${ }^{8}$ High concentrations of $\mathrm{N}$ - nitrosonornicotine (NNN) and heavy metals have been observed in Tuibur. ${ }^{9}$ Smoking meat and vegetables are one method of preservation that are traditionally carried on till today. Consumption of smoked food are also a source of Polycyclic Aromatic Hydrocarbons (PAHs). ${ }^{10}$

Areca nuts commonly known as betel nuts are fruits harvested from a tropical palm tree known as Areca catechu. Areca nuts are popularly consumed by wrapping them in an areca leaf (Piper areca) with slaked lime called as Kuhva. Areca nuts contained tannins, polyphenols and alkaloids which are carcinogenic by creating Reactive Oxygen Species in the presence of slaked lime. ${ }^{11}$ HNSCC is strongly associated with tobacco use, areca nut and alcohol abuse. ${ }^{8,12}$ Acetaldehyde, a metabolic product of alcohol is a highly reactive and is a potent carcinogenic forming DNA adducts and alterations of DNA methylation. ${ }^{13}$ Alcohol is responsible for $21.6 \%$ of Laryngeal cancers, $26.4 \%$ of lip and oral cavity cancers and $30.5 \%$ of pharyngeal cancers. ${ }^{14}$

To our knowledge, this is the first case control study in this population exploring the association of different sites of HNSCC with family history of cancer and different established factors as well as lifestyle habits like consumption of smoked food, zozial, tuibur and local-made alcohol which are distinct to this population.

\section{Materials and methods}

\subsection{Data collection}

Ethical Clearance was obtained from the Institutional Ethics Committee of Civil Hospital Aizawl, Mizoram, India (No.B.12,018/1/13CHA)/IEC/29). Patients who were biopsy proven Head and Neck Squamous Cell Carcinoma at Civil Hospital Aizawl between 2017 and 2019 were included in the study. The samples from the following sites were available for the study: Oral Cavity (ICD-10 codes C00.0 - C06.2), Oropharynx (ICD codes C09.0 - C10.9), Hypopharynx (ICD codes C12 C13.9), Nasopharynx (ICD codes 11.0-11.9) and Larynx (ICD codes C32.0 - C32.2). After obtaining well informed consent, questionnaires comprising of tobacco use in the form of smoking (cigarette), dipping (sahdah), chewing/ingested (gutkha products), tuibur, consumption of alcohol, kuhva (areca nut with/without tobacco), smoked food and family history of cancer were recorded (Supplementary Fig. 1). Control questionnaires were obtained from 200 age-matched healthy participants.

Smoking was measured in pack years as per the National Cancer Institute, USA (http://www.cancer.gov/dictionary?CdrID=306510). Pack years was calculated with sticks per day divided by 10 (one pack contains 10 sticks in this region), which is then multiplied by the years the patient smoked. The patients were categorized into three groups non-smokers, smokers with pack years below average and smokers with pack years above average. For alcohol intake, the level of consumption was measured by multiplying number of days the patient drinks in a week with the duration (years) the patient drank alcohol. The patients were categorized into non-drinkers, below average alcohol consumption and above average alcohol consumption level.

Family history of cancer was recorded to understand whether a patient has any known blood-related family member with cancer at any site. Three classes were formed - Family History of Cancers (FHC), First-
Degree Family History of Cancer (First-Degree FHC) and Second-Degree Family History of Cancer (Second-Degree FHC). First-Degree FHC includes parents and siblings while Second-Degree FHC includes uncles/ aunties, cousins and grandparents, Family History of Cancers includes either First or Second-Degree Family History of Cancer.

\subsection{Statistical analysis}

The data was analysed with SPSS software (Statistical package for social science) version 20.0. Descriptive analysis was done with gender, age-group, smoking (cigarette), alcohol, dipping (sahdah), tuibur, kuhva (areca nut), smoked food and family history of cancer. Logistic Regression Analysis was carried out to calculate the adjusted odds ratio with a $95 \%$ confidence interval (CI) to understand the risk association of the variables with HNSCC cases against the controls. The regression model was adjusted for smoking (cigarette), alcohol, kuhva (areca nut) and FHC.

\section{Results}

In our study, $40.7 \%$ of total participants were males with a statistically significant OR of 6.694 (Tables 1 and 2). The mean age of the participants was 54.66 years. The most affected site was Oral Cavity with 41 patients, followed by Hypopharynx (30) (Supplementary Table 1). The lowest frequency sites were Larynx and Nasopharynx, with a count of 9 each. $48.7 \%$ (146) participants in our study were smokers among which 85 were cases and 61 were control. Among the cases, the most frequent type of cigarette smoked was Zozial (66/85 smokers) (Supplementary Table 1). Smoking level was separated on the basis of average pack-years which is 70 . The smokers with pack years above and below average showed significant p-value, however, a higher risk was shown for pack years above average $(\mathrm{OR}=15.43)$ as compared to pack years below average $(\mathrm{OR}=4.896)$ (Table 2$)$.

The average alcohol consumption level was 20 (Table 2). In the study, $71 \%$ participants were non - drinkers (control - 174 and cases 39); $17 \%$ were below average consumption of alcohol where number of controls was 18 and cases was 33. Majority of the patients (51/63) consumed local made alcohol (Supplementary Table 1). Regression analysis showed an increased risk in high alcohol consumption as the OR for alcohol consumption above average was $5.509(\mathrm{p}=0.00)$ while that of below average alcohol consumption was $4.021(\mathrm{p}=0.001)$.

Regression analysis also showed a non-significant risk for kuhva (areca nut) with an OR of $1.216(0.594-2.497)$. The OR for dipping (sahdah), tuibur and smoked food are $0.364,0.561$ and 0.712 , respectively. Out of the 300 participants, 105 were found to have First-Degree FHC where 58 were that of control and 47 were that of cases. A significant association for cancer risk was observed for First-Degree FHC with an OR of $1.921(\mathrm{p}=0.037)$. No significant association was found with Second-Degree FHC. Fig. 1 represents the distribution of FHC and FirstDegree FHC with duration (range in years) of smoking and alcohol against total HNSCC in the study. The smoking duration was categorized in ranges of non-smokers, below 20, 21-30, 31-40, 41-50 and above 50 years of smoking. The frequency of patients with FHC and First-Degree of FHC was plotted for every range of smoking duration. Except for smokers who smoked less than 20 years, in every other range including the non-smokers, the number of patients having FHC occupies more than $50 \%$ of the total count for each range. Likewise, in alcohol consumption duration, similar graph was plotted for FHC and First-Degree of FHC against non-drinkers to 50 years of alcohol consumption in a ten-year range. In alcohol drinkers, FHC occupied more than $50 \%$ of the total count. Supplementary Fig. 2 represents the distribution of FHC with duration (range in years) of smoking and alcohol consumption against site-wise HNSCC. 
Table 1

Characteristics of Head \& Neck Cancer cases and controls in this study.

\begin{tabular}{|c|c|c|c|c|}
\hline Factors & Variables & $\begin{array}{l}\text { Control n } \\
(\%)\end{array}$ & $\begin{array}{l}\text { Case } \mathrm{n} \\
(\%)\end{array}$ & $\begin{array}{l}\text { TotalN } \\
(\%)\end{array}$ \\
\hline \multirow[t]{2}{*}{ Gender } & Female & $152(85.4)$ & $26(14.6)$ & $\begin{array}{l}178 \\
(59.3)\end{array}$ \\
\hline & Male & $48(39.3)$ & $74(60.7)$ & $\begin{array}{l}122 \\
(40.7)\end{array}$ \\
\hline \multirow[t]{2}{*}{ Age group (years) } & Below 45 & $58(79.5)$ & $15(20.5)$ & $73(24.3)$ \\
\hline & Above 45 & $142(62.6)$ & $85(37.4)$ & $\begin{array}{l}227 \\
(75.7)\end{array}$ \\
\hline \multirow[t]{2}{*}{ Smoking status } & No & $139(90.3)$ & 15 (9.7) & $\begin{array}{l}154 \\
(51.3)\end{array}$ \\
\hline & Yes & $61(41.8)$ & $85(58.2)$ & $\begin{array}{l}146 \\
(48.7)\end{array}$ \\
\hline \multirow[t]{3}{*}{ Smoking Level } & Non-smoker & $139(90.3)$ & $15(15)$ & $\begin{array}{l}154 \\
(51.3)\end{array}$ \\
\hline & $\begin{array}{l}\text { Below } \\
\text { Average }\end{array}$ & $51(49.5)$ & $52(50.5)$ & $\begin{array}{l}103 \\
(34.3)\end{array}$ \\
\hline & $\begin{array}{l}\text { Above } \\
\text { Average }\end{array}$ & $10(23.3)$ & $33(76.7)$ & $43(14.3)$ \\
\hline \multirow[t]{2}{*}{ Alcohol status } & No & $174(81.7)$ & $39(18.3)$ & $\begin{array}{l}213 \\
(71.0)\end{array}$ \\
\hline & Yes & $26(29.9)$ & $61(70.1)$ & $87(29.0)$ \\
\hline \multirow[t]{3}{*}{$\begin{array}{l}\text { Alcohol Consumption } \\
\text { Level }\end{array}$} & Non-drinker & $174(81.7)$ & $39(18.3)$ & $\begin{array}{l}213 \\
(71.0)\end{array}$ \\
\hline & $\begin{array}{l}\text { Below } \\
\text { Average }\end{array}$ & $18(35.3)$ & $33(64.7)$ & $51(17.0)$ \\
\hline & $\begin{array}{l}\text { Above } \\
\text { Average }\end{array}$ & $8(22.2)$ & $28(77.8)$ & $36(12.0)$ \\
\hline \multirow[t]{2}{*}{ Dipping (Sahdah) } & No & $88(61.1)$ & $56(38.9)$ & $\begin{array}{l}144 \\
(48.0)\end{array}$ \\
\hline & Yes & $112(71.8)$ & $44(28.2)$ & $\begin{array}{l}156 \\
(52.0) \\
\end{array}$ \\
\hline \multirow[t]{2}{*}{ Tuibur } & No & $159(66.0)$ & $82(34.0)$ & $\begin{array}{l}241 \\
(80.3)\end{array}$ \\
\hline & Yes & $41(69.5)$ & $18(30.5)$ & $59(19.7)$ \\
\hline \multirow[t]{2}{*}{ Kuhva (Areca Nut) } & No & $75(80.6)$ & $18(19.4)$ & $93(31.0)$ \\
\hline & Yes & $125(60.4)$ & $82(39.6)$ & $\begin{array}{l}207 \\
(69.0)\end{array}$ \\
\hline \multirow[t]{2}{*}{ Smoked food } & No & $43(64.2)$ & $24(35.8)$ & $67(22.3)$ \\
\hline & Yes & $157(67.4)$ & $76(32.6)$ & $\begin{array}{l}233 \\
(77.7)\end{array}$ \\
\hline \multirow[t]{2}{*}{ FHC } & Without & $118(73.3)$ & $43(26.7)$ & $\begin{array}{l}161 \\
(53.7)\end{array}$ \\
\hline & With & $82(59.0)$ & $57(41.0)$ & $\begin{array}{l}139 \\
(46.3)\end{array}$ \\
\hline \multirow[t]{2}{*}{ First Degree FHC } & Without & $142(72.8)$ & $53(27.2)$ & $\begin{array}{l}195 \\
(65.0)\end{array}$ \\
\hline & With & $58(55.2)$ & $47(44.8)$ & $\begin{array}{l}105 \\
(35.0)\end{array}$ \\
\hline \multirow[t]{2}{*}{ Second Degree FHC } & Without & $176(67.7)$ & $84(32.3)$ & $\begin{array}{l}260 \\
(86.7)\end{array}$ \\
\hline & With & $24(60.0)$ & $16(40.0)$ & $40(13.3)$ \\
\hline
\end{tabular}

FHC - Family history of Cancer.

Average alcohol consumption level $=20$.

Average smoking level (pack years) $=70$.

\section{Discussion}

Smoking has been strongly associated with Head and Neck Cancer. ${ }^{9}$ In our study, we found that smoking behavior, whether in low or heavy quantity, showed significant risk. It has been observed that the risk increases in a dose-dependent manner with increase in pack years, duration or frequency of cigarette smoked. ${ }^{15}$ This holds true in our case as the OR increased by three-fold in $>70$ pack years (OR $=15.438,95 \%$ CI 5.989-39.793) as compared to $\leq 70$ pack years (OR $=4.896,95 \%$ CI 2.352-10.191). More than 70 carcinogens and heavy metals like Cadmium (Cd), Mercury ( $\mathrm{Hg}$ ), Arsenic (As), Nickel (Ni), Lead (Pb) and
Table 2

Regression Analysis of risk factors with cases-controls.

\begin{tabular}{|c|c|c|c|c|c|}
\hline Factors & Variables & $\begin{array}{l}\text { Control } \\
\text { (n) }\end{array}$ & $\begin{array}{l}\text { Case } \\
\text { (n) }\end{array}$ & $\begin{array}{l}\mathrm{p}- \\
\text { value }\end{array}$ & $\begin{array}{l}\text { Odds Ratio }{ }^{\mathrm{a}}(95 \% \\
\text { Confidence } \\
\text { Interval) }\end{array}$ \\
\hline \multirow[t]{2}{*}{ Gender } & Female & 152 & 26 & \multicolumn{2}{|l|}{ Reference } \\
\hline & Male & 48 & 74 & 0 & $\begin{array}{l}6.694 \\
(3.278-13.669)\end{array}$ \\
\hline \multirow{2}{*}{$\begin{array}{l}\text { Age group } \\
\text { (years) }\end{array}$} & Below 45 & 58 & 15 & \multicolumn{2}{|l|}{ Reference } \\
\hline & Above 45 & 142 & 85 & 0 & $\begin{array}{l}3.979 \\
(1.768-8.955)\end{array}$ \\
\hline \multirow[t]{2}{*}{ Smoking status } & No & 139 & 15 & \multicolumn{2}{|l|}{$\overline{\text { Reference }}$} \\
\hline & Yes & 61 & 85 & 0 & $\begin{array}{l}6.703 \\
(3.360-13.375)\end{array}$ \\
\hline \multirow[t]{3}{*}{ Smoking Level } & $\begin{array}{l}\text { Non- } \\
\text { smoker }\end{array}$ & 139 & 15 & \multicolumn{2}{|l|}{ Reference } \\
\hline & $\begin{array}{l}\text { Below } \\
\text { Average }\end{array}$ & 51 & 52 & 0 & $\begin{array}{l}4.896 \\
(2.352-10.191)\end{array}$ \\
\hline & $\begin{array}{l}\text { Above } \\
\text { Average }\end{array}$ & 10 & 33 & 0 & $\begin{array}{l}15.438 \\
(5.989-39.793) \\
\end{array}$ \\
\hline \multirow[t]{2}{*}{ Alcohol status } & No & 174 & 39 & \multicolumn{2}{|l|}{ Reference } \\
\hline & Yes & 26 & 61 & 0 & $\begin{array}{l}4.527 \\
(2.354-8.706)\end{array}$ \\
\hline \multirow{3}{*}{$\begin{array}{l}\text { Alcohol } \\
\text { Consumption } \\
\text { Level }\end{array}$} & $\begin{array}{l}\text { Non- } \\
\text { drinker }\end{array}$ & 174 & 39 & \multicolumn{2}{|l|}{$\overline{\text { Reference }}$} \\
\hline & $\begin{array}{l}\text { Below } \\
\text { Average }\end{array}$ & 18 & 33 & 0.001 & $\begin{array}{l}4.021 \\
(1.890-8.557)\end{array}$ \\
\hline & $\begin{array}{l}\text { Above } \\
\text { Average }\end{array}$ & 8 & 28 & 0 & $\begin{array}{l}5.509 \\
(2.189-13.918)\end{array}$ \\
\hline \multirow{2}{*}{$\begin{array}{l}\text { Dipping } \\
\quad \text { (Sahdah) }\end{array}$} & No & 88 & 56 & \multicolumn{2}{|l|}{$\overline{\text { Reference }}$} \\
\hline & Yes & 112 & 44 & 0.364 & $\begin{array}{l}0.753 \\
(0.408-1.389)\end{array}$ \\
\hline \multirow[t]{2}{*}{ Tuibur } & No & 159 & 82 & \multicolumn{2}{|l|}{ Reference } \\
\hline & Yes & 41 & 18 & 0.561 & $0.8(0.377-1.697)$ \\
\hline Kuhva (Areca & No & 75 & 18 & \multicolumn{2}{|l|}{ Reference } \\
\hline Nut) & Yes & 125 & 82 & 0.59 & $\begin{array}{l}1.218 \\
(0.594-2.497)\end{array}$ \\
\hline \multirow[t]{2}{*}{ Smoked food } & No & 43 & 24 & \multicolumn{2}{|l|}{ Reference } \\
\hline & Yes & 157 & 76 & 0.351 & $\begin{array}{l}0.712 \\
(0.349-1.454)\end{array}$ \\
\hline \multirow[t]{2}{*}{ FHC } & No & 118 & 43 & \multicolumn{2}{|l|}{ Reference } \\
\hline & Yes & 82 & 57 & 0.948 & $\begin{array}{l}1.021 \\
(0.553-1.883)\end{array}$ \\
\hline First Degree & No & 142 & 53 & \multicolumn{2}{|l|}{$\overline{\text { Reference }}$} \\
\hline FHC & Yes & 58 & 47 & 0.037 & $\begin{array}{l}1.921 \\
(1.040-3.547)\end{array}$ \\
\hline Second Degree & No & 176 & 84 & \multicolumn{2}{|l|}{ Reference } \\
\hline FHC & Yes & 24 & 16 & 0.088 & $\begin{array}{l}0.464 \\
(0.192-1.122)\end{array}$ \\
\hline
\end{tabular}

FHC - Family History of Cancer.

p-value is significant at $5 \%$ level $(<0.05)$.

${ }^{\text {a }}$ OR adjusted with smoking, alcohol, kuhva and FHC.

Chromium (Cr) have been found in branded cigarettes including Indian brands. ${ }^{16-20}$ Exposure to heavy metals have also been associated with the risk of Head and Neck Cancer. In Tunisian population, the concentration of $\mathrm{Cd}, \mathrm{Ni}$, As and $\mathrm{Cr}$ were higher in Head and Neck Cancer tumor tissues among the smokers as compared to non-smokers. ${ }^{21}$ Studies have shown that the mechanism of carcinogenesis of $\mathrm{Cd}, \mathrm{Ni}$ and $\mathrm{Cr}$ include induction of oxidative stress and inhibition of DNA repair, apoptosis and methylation. ${ }^{21}$

Majority of the patients in our study were found to frequently smoke zozial. Tobacco filler used for making zozial is found to contain significantly high concentration levels of aluminium, manganese and silicon. ${ }^{10}$ Other heavy element species, such as, arsenic, cadmium, chromium, cobalt, copper, iron, lead and mercury were also detected with higher concentration levels as compared to other commonly consumed brands. ${ }^{9,16}$ Because of the high chlorine content in tobacco 
(a). Distribution of FHC and First-Degree FHC with Smoking Duration. $\uparrow$

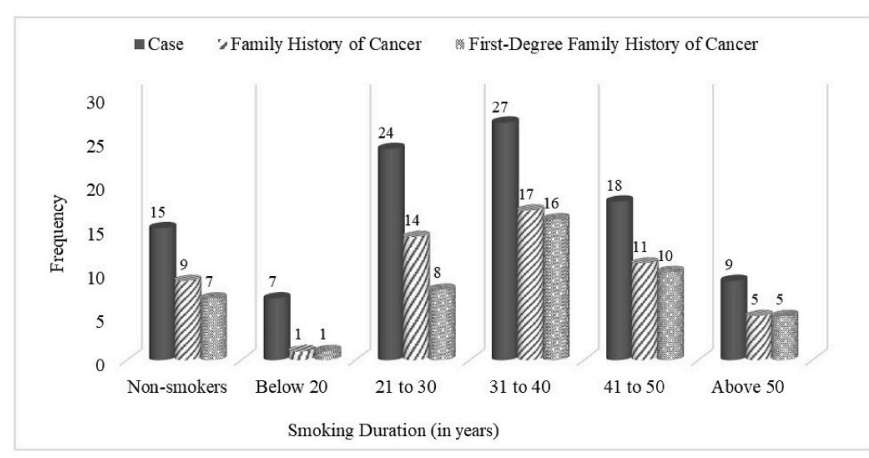

(b). Distribution of FHC and First-Degree FHC with Alcohol Consumption

Duration. †

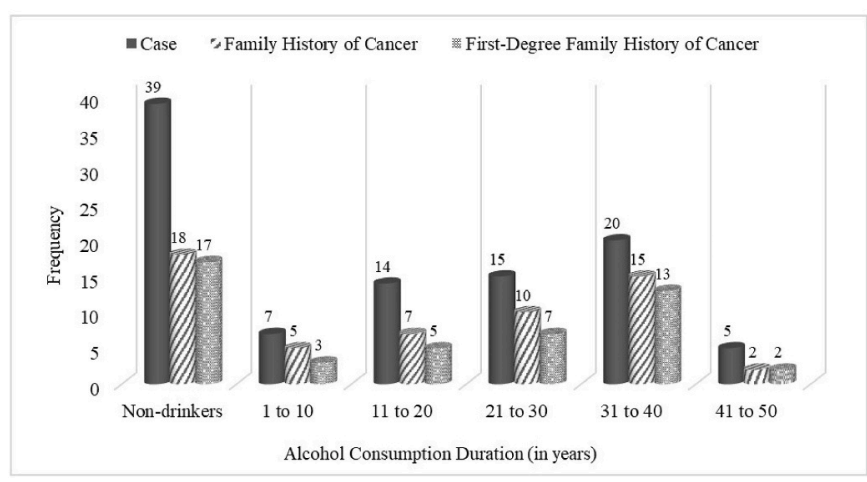

Fig. 1. (a). Distribution of FHC and first-degree FHC with smoking duration. $\dagger$

$\dagger$ The solid grey bars indicate the total number of patients in every range; the striped bars indicate the number of patients having FHC. The dotted bars indicate the number of First-Degree FHC.

Fig. 1 (b). Distribution of FHC and first-degree FHC with alcohol consumption duration. $\dagger$.

and the low quality of paper used to roll it, smokers of zozial need to puff more frequently to keep it lighted, resulting in increased inhalation of tobacco smoke. ${ }^{22}$ This might also impose a greater risk in developing HNSCC in this population. Tobacco plants used to produce zozial are grown by the local people in their annual farm cultivation. Tobacco plants naturally take up heavy metals from the soil and accumulate in their leaves. ${ }^{23}$ However, there are no data estimating the level of these metallic compounds present neither in the soil nor in the pesticides/fertilizers used in the land where the tobacco plants were grown.

Smokeless tobacco in the form of dipping (sahdah) and tuibur showed a weak association with HNSCC in our analysis. Use of smokeless tobacco has been strongly associated with Oral Cavity cancer. ${ }^{24}$ Due to widespread use of smokeless tobacco, Oral Cancer is a burden in India. ${ }^{25}$ The low OR in our analysis might be because of the infrequent practice as compared to smoking among the cases as well as control in the small set of samples obtained. Among the risk factors of Oral Cavity cancer is consumption of Areca Nut, which contains carcinogenic compounds that induce the production of Reactive Oxygen Species. ${ }^{12,25}$ Despite the frequent consumption of Areca Nut (76/100 cases), regression analysis showed a non-significant association with an OR of 1.218 (CI 0.594-2.497). Given the evidences in other studies, the impact of smokeless tobacco and areca nut chewing direct more towards the primary site of exposure i.e., Oral Cavity. ${ }^{26}$ However, our small sample size restricts site-wise analysis which is one of the limitations in this study.

Alcohol consumption has been associated with multiple cancers like Esophageal, Liver and Gastric Cancer. ${ }^{1}$ The mechanisms by which alcohol causes cancer have been described ${ }^{13,14}$ Alcohol is metabolized into acetaldehyde which is a carcinogenic compound that disturb the stability of DNA. ${ }^{13}$ In a case-control study where alcohol intake was categorized based on amount of drinks/day (One drink is equivalent to $30 \mathrm{ml}$ of spirits), the Odd's Ratio was 2.1, 5.0,12.2 and 21.1 for drinkers of 3-4, 5-7, 8-11 and $>12$ drinks/day, respectively as compared to $<2$ drinks/day. ${ }^{27} \mathrm{~A}$ similar trend was also observed in a meta-analysis where they considered the intensity in terms of midpoint of $g$ of alcohol per day - light $(\leq 12.5 \mathrm{~g})$, moderate $(\leq 50 \mathrm{~g})$ and heavy $(>50 \mathrm{~g})$. The risk increases as the consumption increases from light to moderate to heavy in oral cavity and pharyngeal cancer with an estimated Risk Ratio of 1.13, 1.83 and 5.13, respectively. ${ }^{28}$ On the basis of frequency of drinks in day wise, a study in Taiwan reported an increased risk in increase in frequency when partitioning into monthly, weekly and daily consumption of alcohol. ${ }^{29}$ The trends in other studies mentioned above and our regression analysis clearly showed a significant high dose dependent risk of HNSCC with that of alcohol consumption. The drawback in our study is that the raw and imprecise processing limits the option of calculating the amount of alcohol in a drink because there is no estimation of percentage or volume of alcohol in the most frequently consumed 'Local' drink. Regardless of the amount or duration of exposure to alcohol, we believe that there are high chances that other compounds might be present and this may somehow be attributable to the harmful effects leading to increase risk in not only head and neck cancer, but cancer in other sites and other diseases as well. It is recommended that further studies on the Local drinks are imperative to confirm this assumption for public awareness.

The association between HNSCC and environmental factors especially smoking and alcohol intake has been extensively investigated. ${ }^{30}$ Our small set of a hundred case study showed that apart from smoking and alcohol, first-degree family history of cancer may also be one of the major risk factors for HNSCC in this population with an adjusted OR of 1.921 (95\% CI 1.040-3.547). In an ICARE study in France, the OR was reported to be 1.9 (95\% CI 1.2-2.8) in Oral Cavity cancer among patients with first-degree family history of cancer. ${ }^{31}$ Associations of alcohol, smoking and FHC have been described in several studies. Analysis conducted by the International Head and Neck Cancer Epidemiology (INHANCE) consortium compared the association of alcohol, smoking and FHC in a case control study comprising of 8967 cases where the OR was 7.2 (95\% CI 5.5-9.5) among patients with family history of cancer who were smokers and alcohol users. ${ }^{32}$ Later, in a 25 case-control study, a strong association (OR: 2.27, 95\% CI: 1.26-4.10) was observed between FHC and Head and Neck Cancer in patients below 45 years. ${ }^{33}$

Evidences suggesting potential familial component have been reported in Head and Neck cancer based on tobacco and alcohol metabolism, cell cycle and DNA repair pathway. A germline CDKN2A mutation resulting in a premature codon termination have been detected in a 48 years old proband with Hypopharyngeal cancer. ${ }^{34}$ Increased mutational burden in three key genes - FANCL, FANCE and FANCD2 genes in the FANC pathway have also been identified among 417 head and neck cancer patients. ${ }^{35}$ Polymorphisms in the gene RAD51 and XRCC3 have also been reported to increase the risk of HNC by a 2.5 and 16 - fold respectively. ${ }^{36}$ In the North Eastern India, Choudhury et al. had reported polymorphisms in XRCC1 and XRCC2 and their interactions with tobacco consumption might exert an influence on the susceptibility of HNSCC. ${ }^{37}$ Other metabolic enzymes including ALDH2, GST genes and Cytochrome p450 genes have also been reported to increase head and neck cancer risk. ${ }^{38}$

In Fig. 1 (a) and (b), the frequency of FHC occupies half of every count in the range of alcohol consumption and smoking durations including non-drinkers and non-smokers. Moreover, in the two sites Oral Cavity and Hypopharynx, the number of cases having FHC is higher compared to the other sites (Supplementary Figs. 2(a) and (b)). Alcohol consumption and smoking have been practiced for many generations and to this day they are the vices of men and women in the state. In addition to these practices, the incidence of HNSCC with family history 
of cancer among the patients is high and there seems to be a potential influence of family history of cancer regardless of exposure to alcohol and smoking. Exposure to the risk factors and environmental factors for many generations in a small endogamous population might have led to genetic alterations making the population predisposed to cancer reflecting more among patients with family history of cancer. This has to be proved by conducting genetic mutation studies in the families. Investigation on the polymorphism present in the metabolic pathway of tobacco and alcohol will elucidate the associated risk that might have modulated familial tendency of head and neck cancer in this population.

\section{Conclusion}

Our analysis seems to indicate a significant interaction of risk factors between lifestyle habits and family history of cancer. Although alcohol and smoking are established risk factors for HNSCC, the high incidence of patients having family history of cancer even in non-smokers and nondrinkers in our study, seems to impose family history of cancer as an attributable factor. Further genetic screening with larger number of cases is needed to evaluate the degree of increased risk with alcohol and tobacco and more importantly, the germline effect on tumour development in HNSCC in this population.

\section{Limitations}

While this study covers the different sites of Head and Neck Cancer, the low sample size limits site-wise analysis. Most of the data are based on questionnaire alone, certain clinical information like presence of absence of HPV, stages of the cancer and blood profile are not obtained.

\section{Funding}

This study did not receive any grant from funding agencies.

\section{Declaration of competing interest}

The authors declare that they have no conflict of interests.

\section{Acknowledgement}

The author LP gratefully acknowledges the Financial support from ICMR, Govt of India (No. 79/3/NE/PROJ/2016-NCD-III dated July 26, 2018). The author ZZ thanks the DST-INSPIRE programme for the fellowship and contingency grant (No: DST/INSPIRE Fellowship/ [IF180827]). We are very grateful to Dr. Zorammawia (L) Civil Hospital for his support and help in recruitment of patients.

\section{Appendix A. Supplementary data}

Supplementary data to this article can be found online at https://doi. org/10.1016/j.cegh.2021.100954.

\section{References}

1 Sung H, Ferlay J, Siegel RL, et al. Global cancer statistics 2020: GLOBOCAN estimates of incidence and mortality worldwide for 36 cancers in 185 countries. Ca - Cancer J Clin. 2021;71(3):209-249. https://doi.org/10.3322/caac.21660.

2 Mathur P, Sathishkumar K, Chaturvedi M, et al. Cancer statistics, 2020: report from national cancer registry programme, India. JCO Glob Oncol. 2020;6:1063-1075. https://doi.org/10.1200/GO.20.00122.

3 Report of national cancer registry programme (ICMR-NCDIR). Bengaluru, India http S://www.ncdirindia.org/All_Reports/Report_2020/default.aspx; 2020.

4 Gingerich MA, Smith JD, Michmerhuizen NL, et al. Comprehensive review of genetic factors contributing to head and neck squamous cell carcinoma development in lowrisk, non traditional patients. Head Neck. 2018;40(5):943-954. https://doi.org/ 10.1002/hed.25057.

5 Lacko M, Braakhuis BJ, Sturgis EM, et al. Genetic susceptibility to head and neck squamous cell carcinoma. Int J Radiat Oncol Biol Phys. 2014;89(1):38-48. https://doi. org/10.1016/j.ijrobp.2013.09.034.
6 Fostira F, Koutsodontis G, Vagia E, et al. Predisposing germline mutations in young patients with squamous cell cancer of the oral cavity. JCO Precis Oncol. 2018;2:1-8.

7 Huang Y, Zhao J, Mao G, et al. Identification of novel genetic variants predisposing to familial oral squamous cell carcinomas. Cell Discov. 2019;26(5):57. https://doi.org/ 10.1038/s41421-019-0126-6.

8 Jethwa AR, Khariwala SS. Tobacco-related carcinogenesis in head and neck cancer. Cancer Metastasis Rev. 2017;36(3):411-423. https://doi.org/10.1007/s10555-0179689-6.

9 Lalrammawia K, Buragohain A, Kakki B, et al. Determination of multi elements in tobacco plant of northeast India by neutron activation analysis and atomic absorption spectrometry. Biol Trace Elem Res. 2021. https://doi.org/10.1007/ s12011-021-03040-2.

10 Gomaa EA, Gray JI, Rabie S, Lopez-Bote C, Booren AM. Polycyclic aromatic hydrocarbons in smoked food products and commercial liquid smoke flavourings. Food Addit Contam. 1993;10(5):503-521. https://doi.org/10.1080/ 02652039309374174.

11 Sharan RN, Mehrotra R, Choudhury Y, Asotra K. Association of betel nut with carcinogenesis: revisit with a clinical perspective. PLoS One. 2012;7(8), e42759. https://doi.org/10.1371/journal.pone.0042759.

12 Alsahafi E, Begg K, Amelio I, et al. Clinical update on head and neck cancer: molecular biology and ongoing challenges. Cell Death Dis. 2019;10(8):540. https:// doi.org/10.1038/s41419-019-1769-9, 15.

13 Brooks PJ, Zakhari S. Acetaldehyde and the genome: beyond nuclear DNA adducts and carcinogenesis. Environ Mol Mutagen. 2014;55(2):77-91. https://doi.org/ 10.1002/em.21824.

14 Marziliano A, Teckie S, Diefenbach MA. Alcohol-related head and neck cancer: summary of the literature. Head Neck. 2020;42(4):732-738. https://doi.org/ 10.1002/hed.26023.

15 Hashibe M, Brennan P, Benhamou S, et al. Alcohol drinking in never users of tobacco, cigarette smoking in never drinkers, and the risk of head and neck cancer: pooled analysis in the International Head and Neck Cancer Epidemiology Consortium. J Natl Cancer Inst. 2007;99(10):777-789. https://doi.org/10.1093/jnci/djk179.

16 Khariwala SS, Hatsukami D, Hecht SS. Tobacco carcinogen metabolites and DNA adducts as biomarkers in head and neck cancer: potential screening tools and prognostic indicators. Head Neck. 2012;34(3):441-447. https://doi.org/10.1002/ hed. 21705.

17 Raju NJ, Kofod M, Isenbeck-Schroter M, Muller G. Heavy metal content of Indian cigarettes. Toxicol Environ Chem. 1999;72:215-219.

18 Dhaware D, Deshpande A, Khandekar RN, Chowgule R. Determination of toxic metals in Indian smokeless tobacco products. Sci World J. 2009;9:1140-1147. https://doi.org/10.1100/tsw.2009.132.

19 Ashraf MW. Levels of heavy metals in popular cigarette brands and exposure to these metals via smoking. Scie World J 2012. 2012:729430. https://doi.org/10.1100/ 2012/729430.

20 Janaydeh M, Ismail A, Zulkifli SZ, Omar H. Toxic heavy metal ( $\mathrm{Pb}$ and $\mathrm{Cd}$ ) content in tobacco cigarette brands in Selangor state, Peninsular Malaysia. Environ Monit Assess. 2019;191(10):637. https://doi.org/10.1007/s10661-019-7755-y.

21 Khlifi R, Hamza-Chaffai A. Head and neck cancer due to heavy metal exposure via tobacco smoking and professional exposure: a review. Toxicol Appl Pharmacol. 2010; 248(2):71-88. https://doi.org/10.1016/j.taap.2010.08.003.

22 Laugesen M, Epton M, Frampton CM, Glover M, Lea RA. Hand-rolled cigarette smoking patterns compared with factory-made cigarette smoking in New Zealand men. BMC Publ Health. 2009;9:194. https://doi.org/10.1186/1471-2458-9-194.

23 Regassa G, Chandravanshi BS. Levels of heavy metals in the raw and processed Ethiopian tobacco leaves. SpringerPlus. 2016;5:232. https://doi.org/10.1186/ s40064-016-1770-z.

24 Siddiqi K, Shah S, Abbas SM, et al. Global burden of disease due to smokeless tobacco consumption in adults: analysis of data from 113 countries. BMC Med. 2015;13:194. https://doi.org/10.1186/s12916-015-0424-2.

25 Wyss AB, Hashibe M, Lee YA, et al. Smokeless tobacco use and the risk of head and neck cancer: pooled analysis of US studies in the INHANCE consortium. Am J Epidemiol. 2016;184(10):703-716. https://doi.org/10.1093/aje/kww075.

26 Lee YA, Li S, Chen Y, et al. Tobacco smoking, alcohol drinking, betel quid chewing, and the risk of head and neck cancer in an East Asian population. Head Neck. 2019;41 (1):92-102. https://doi.org/10.1002/hed.25383.

27 Altieri A, Bosetti C, Gallus S, et al. Wine, beer and spirits and risk of oral and pharyngeal cancer: a case-control study from Italy and Switzerland. Oral Oncol. 2004;40(9):904-909. https://doi.org/10.1016/j.oraloncology.2004.04.005.

28 Bagnardi V, Rota M, Botteri E, et al. Alcohol consumption and site-specific cancer risk: a comprehensive dose-response meta-analysis. Br J Cancer. 2015;112(3): 580-593. https://doi.org/10.1038/bjc.2014.579.

29 Huang CC, Hsiao JR, Lee WT, et al. Investigating the association between alcohol and risk of head and neck cancer in taiwan. Sci Rep. 2017;7(1):9701.

30 Miranda-Galvis M, Loveless R, Kowalski LP, Teng Y. Impacts of environmental factors on head and neck cancer pathogenesis and progression. Cells. 2021;10(2): 389. https://doi.org/10.3390/cells10020389.

31 Radoï L, Paget-Bailly S, Cyr D, et al. Tobacco smoking, alcohol drinking and risk of oral cavity cancer by subsite: results of a French population-based case-control study, the ICARE study. Eur J Cancer Prev. 2013;22(3):268-276. https://doi.org/10.1097/ CEJ.0b013e3283592cce.

32 Negri E, Boffetta P, Berthiller J, et al. Family history of cancer: pooled analysis in the international head and neck cancer Epidemiology consortium. Int J Cancer. 2009;124 (2):394-401. https://doi.org/10.1002/ijc.23848.

33 Toporcov TN, Znaor A, Zhang ZF, et al. Risk factors for head and neck cancer in young adults: a pooled analysis in the INHANCE consortium. Int J Epidemiol. 2015;44 (1):169-185. https://doi.org/10.1093/ije/dyu255. 
34 Cabanillas R, Astudillo A, Valle M, et al. Novel germline CDKN2A mutation associated with head and neck squamous cell carcinomas and melanomas. Head Neck. 2013;35(3):E80-E84. https://doi.org/10.1002/hed.21911.

35 Chandrasekharappa SC, Chinn SB, Donovan FX, et al. Assessing the spectrum of germline variation in Fanconi anemia genes among patients with head and neck carcinoma before age 50. Cancer. 2017;123(20):3943-3954. https://doi.org/ 10.1002/cncr.30802.

36 Kayani MA, Khan S, Baig RM, Mahjabeen I. Association of RAD 51135 G/C, 172 G/T and XRCC3 Thr241Met gene polymorphisms with increased risk of head and neck cancer. Asian Pac J Cancer Prev APJCP. 2014;15(23):10457-10462. https://doi.org/ 10.7314/apjcp. 2014.15.23.10457.

37 Choudhury JH, Choudhury B, Kundu S, Ghosh SK. Combined effect of tobacco and DNA repair genes polymorphisms of XRCC1 and XRCC2 influence high risk of head and neck squamous cell carcinoma in northeast Indian population. Med Oncol. 2014; 31(8):67. https://doi.org/10.1007/s12032-014-0067-8.

38 Venugopal R, Bavle RM, Konda P, Muniswamappa S, Makarla S. Familial cancers of head and neck region. J Clin Diagn Res. 2017;11(6):ZE01-ZE06. https://doi.org/ $10.7860 / J C D R / 2017 / 25920.9967$. 